\title{
THE PUBLIC SPACE THROUGH AN AESTHETIC ETHICS
}

\author{
Alessio Tommasoli \\ European University of Rome, Human studies Department, Italy \\ Lavinia Tommasoli \\ Sapienza University of Rome, Department of Urban planning, Design and \\ Technology of Architecture, Italy
}

\begin{abstract}
The contemporary city is based on the interaction between different systems. If we take in consideration the perspective which represents the city as a cultural event (Settis, 2017), the relation, the paper aims to analize, will be between human being and its rapresentation. If we consider the reciprocal influence of the individual and the society, we understand the crisis of the contemporary city as a consequence and a cause, at the same time, of the "crisis of presence"'S ANTHROPOLOGICAL CONCEPT. Therefore the contemporary city can be a crucial tool through which developing a reintegration process: take action on the city means make an ethos of transcendence. The paper analyze two case studies aim at redefining the sense of community of urban citizens.
\end{abstract}

\section{$1 \quad$ Being-in the world}

A society is based on the relation between human beings. EXACTLY In the specific, it is based on the relation between a single individual and a plurality of individuals, that is the community. However, on the other hand, such a relation determines the identity of a human being, because it is a continuous process of individualization. It is indeed the determination of a complex and continuous relation between the subject and the society, that the subject expresses through its behaviour. "Agere sequitur esse", writes St. Thomas, explaining the mutual relation in which the essence and the behaviour influence each other, so to make a not-determined subject who constantly works on its identity. Actually, our present western society is determined by an anxiety of belonging and of exclusion from community. It is a cultural crisis that we can consider as the origin of a crisis of the society and of the contemporary city which we call "Crisis of presence". It is a concept created by an italian anthropologist Ernesto De Martino: through the concept of "presence" he means an awareness of society's memories and past experiences. It is indeed the result of a long empirical research that he makes during the 
60 's in some ethnographic expeditions in the south of Italy, where he finds what he calls "the magic world": a society where the magic exists, because the people believe in it. They act as if it is real and consequently their behaviour belongs to such a magic world. The expeditions of De Martino highlights a particular pathology of this society: the "Tarantism". It is not a phyisical disease infected by the bite of a fields spider (as the population thought), but a psychological matter that comes from the stress of a social exclusion, that is a "Crisis of presence". A social matter that turns into a mental disease and that influences the whole body. The magical idea of a trance is what exactly resolves the social matter: since the subject is affected by Tarantism, it is reintegrated into the society as a sacred human being through some musical rituals. These rituals evoque some traditions, histories, myths that belong to the culture of the community and that strengthen it. This is what De Martino calls "Ethos of transcendence": a metaphysical process of reintegration of the possessed into the magic culture he belongs and a concrete process of reintegration of the single individual into the community he belongs. That is, exactly, a new determination of the individual identity and a new determination of the society in the continuous relation between them. Even if there is not a connection between the anthropology's researches of De Martino and the urban regeneration of the city, the aim we focus on this article is a urban anthropology that works through a philosophical concept that comes from an existential translation of Martin Heidegger's Dasein: being-in-the-world, the specific world of a society, with its culture (traditions, myths, history, beliefs and rituals) that strengthens a community. ${ }^{1}$ It is in this perspective that the paper higlights the opportunity offered by the strategy of urban regeneration as a multi-objective process: recomposing the identity of a community throught the interaction of the social, economic and environmental system. The selected space depute to the re-creation of urban community are the open public spaces in which society have been always represents itself, in order to make an Ethos of trascendence. These spaces are the assigned elements to strenghthen the public image of the city, areas of consensus (Lynch, 1964), encounter between the individual and a common culture, which valorize a collective memories. Taking the first step from the urban strategy of the European Commission in the 80's, launching the Urban Pilot Project (Phase I: 1989-1994, e Fase II: 19971999), than the URBAN I (1994-1999) e URBAN II (2000-2006) (De Santiago Rodríguez, 2017) passing through the Unesco Declaration

(1) 1 Heidegger, M, Building Dwelling Thinking, from Poetry, Language, Thought, translated by Albert Hofstadter, Harper Colophon Books, New York, 1971 
about immaterial heritage, as the identuty of a community, scientific international debate has been defining different goals between which, one, is the most connected to the Ethos of Trascendence: "make cities and human settlements inclusive, safe, resilient and sustainable" (UN, 2015).

\section{$2 \quad$ Guide lines as a main goal}

There is a polarity between the morphology and the symbolism of a place. The form of an open public space, like a square, is universally recognizable both as a framework to group house in a settlement, than as a courtyard with a symbolic value for inhabitants: "we might almost infer the existence of a kind of social ritual, which produces a perfect match between individual and collective"(Krier, 1979). The course of the market had led to a continue metamorphosis of society. Contemporary cities performe these changes through a loss of symbolism: the lack of open public spaces represents today the crisis of presence. The main goal of the paper is to define guide lines to guarantee open public spaces, which, through morphological, structural and functional interventions, can regain human being consciousness of the sense of community, executing the ritual Presence of human being.

\section{$3 \quad$ How to look for guide lines in open public space}

Through an inductive method, the paper analyzes two case studies, different both in scale than in the object of the analysis, in order to define strategical guide lines for a network of public spaces dissemenated in the urban territory capable of recreating the rituality of the community. The first one is the urban regeneration of a part of Lisbon, a key study to define strategical and general guide lines, meanwhile the second case is the one of Tevereterno, an association based on the vision of an artist, Kristin Jones, aiming at valorizing the river Tevere as a linear open public space. The two cases are placed in fluvial spaces: natural components of landscape which passing through the city. They are caesur and at the same time a continuity: border. The morpholgy of being-inpresence can be rapresented by the limit or the border. Two different concepts which represent the phenomenological transposition of both phisical than conceptual space. The limit is what prevent by an action, which can be a moviment of a person to another (being in presence with), or a prevention from a moviment in a space (being in presence in). The border is instead the delimitation of a line that both phisically than metaphorically represents a continuity of moviment with the consciuscness of a detachment. A border between people can be the line of respect between them, taking in consideration the presence of the other. The phisical border is the definition of a space which can be 
crossed or of a space which can contain, taking in consideration it as an instruments of urban policy and strategy. We indeed can state the border as an advantageus element: it enriches the human being with a new knowledge and it elevates space with a new meaning. Since it's origin Civility used to settle itself on the border between soil and water, near the limit of a see side front or a river front. These had led to the creation of communities.

\section{$4 \quad$ Between city and water in Lisbon}

\subsection{People as the third interacting urban component}

The case "Devolver o Tejo às Pessoas, intervenções na Frente Ribeirinha - Baixa" led us enter into the main focus of the urban regeneration: people. It is clear from the plan that this part of the city is fragmantated in tree different settings: in the middle part there is a rinascimental planned, on the east side the ancient city, and on the opposite side there is an area in-between, designed according with the rinascimental axises togheter with ancient tissues. The morphological discontinuity is resolved throught out the intervention: a functional program setteld along the river as a connection with its articulation between the west riverside area, the hill of "San Francisco" and the urban area "Nascente da Ribeira das naus" and, at the same time, as the main interface of public transport: inland waterways, railways, buses, trams and subways. The first fase of the project, finished in 2013, named "Requalificação do espaço público cais do sodré / corpo sant", aims at valuing the use of public space by the pedestrian through the extension pestrian paths, namely the riverside walk, recovery of the typology of the Square-Garden, "reconstruction" the Largo do Corpo Santo, increased afforestation and renovation of urban furniture in the new areas of residence. The project answer to the will of "preserve, reuse and enhance the pre-existing distinctive elements of this space".

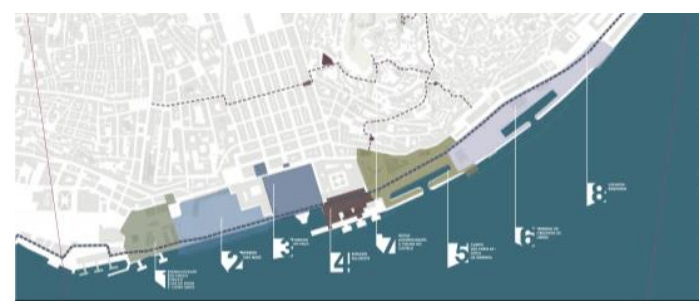

Fig. 1

The functional programme of the urban regeneration in Lisbon 4.2 Space of awareness

The main focus of the intervention is the open public space, as a fluid

(2) The project is available at: http://tevereterno.org/progetti/triumphs-and-laments/ 
involving all the different function in a continue path. The open public space represents "the space of the awareness": citizens can get back to represents themselves as an ancient urban ritual. An urban regeneration with its integrated strategy purposes a solution for the different systems: the connective, the recreational, the cultural and ritual ones. The rite that was once considered daily interrelationship between man and water as a tool of work and sustenance, now it opens the possibility of new relational definitions.

\section{$5 \quad$ Between city and water in Rome}

\subsection{A linear centrality}

The case of Rome is about the management of a part of the city which is depute, according to the general development plan of Rome of 2008, to be a strategical area ${ }^{3}$. The paper aims to introduce a specific intervention on a part of the river organized by the association Tevereterno Onlus, which creates the event "PiazzaTevere". The main goal is to give back to citizens the river as an open public space, throught cultural events. Focused more on the management of the area this case is not properly a case of urban regeneration but a case of cultural intervention in the city, composed by a startegical functional programme.

\subsection{Mythology as ritual}

"Triumphs and Laments" is a site-specific artistic work, by the South African artist William Kentridge, 500 meters long, representing about 80 figures, up to 10 meters high, that give life to a procession of silhouettes along the Tiber, in the stretch between Ponte Sisto and Ponte Mazzini. The figures represent reinterpretations of the artist of an iconographic selection of characters and historical facts that have marked the millenary history of Rome from the classical and mythical age to the modern events of the most recent past. It was inaugurated with an extraordinary musical and theatrical free event, conceived in collaboration with Philip Miller that superimposed the figures realized on the wall other figures created with an infinite play of Chinese shadows. This event has brought back to memory the ancient relationship that once used to connect the inhabitants of Rome with their river: a sacred place. Untill the ' 60 the city used to act a ritual event each year: a wedding between a princess (usually a famous italian woman) and the river. The urban tissue as a cognitive experience:it organizes what we see on the basis of imaginative, emotive, identifying and memorial components, revealing themselves through a satisfaction or

(3) Ambiti di Trasfromazione Startegica referring to: http://www.urbanistica.comune.roma.it/prg-adottato/prg-adottato-elaborati-descrittivi/prgadottato-d7.html 
dissatisfaction that leads to the recognition of the value or disvalue of what we see (D'Angelo, 2010).

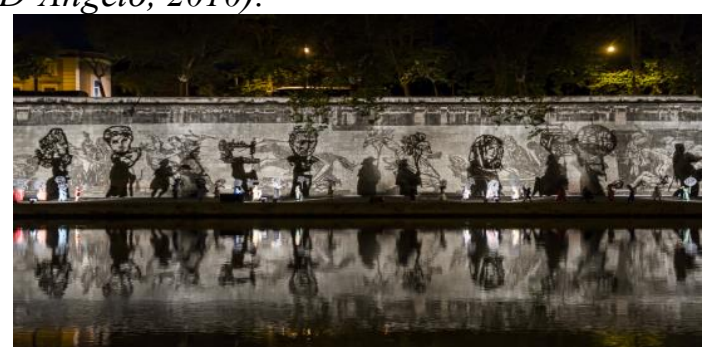

Fig. 2

Triumphs and Laments, Tevere, Rome

\section{$7 \quad$ Conclusions}

The crisis of presence is strictly connected to the crisis of the contemporary city because of the reciprocal influence between the individual and the society. Therefore we must think about a urban regeneration as an ethos of transcendence: a reintegration of the individual in the society through a cultural process that is a ritual in which live the community's traditions, myths, history and beliefs. Thus we highlighted the urban regeneration as this cultural process recomposes the identity of a community and of the individual. It means that the recreation of the urban community through the re-generation of the public spaces is an ethical work. In this way, the case studies of Lisbon and Rome helped us to understand why and how can be succesfully realized such an anthropological process of urban regeneration in the contemporary cities. The cited UN goal is a cornerstone that higlights the global necessity to resolve the urban problem of inclusion. An inclusive city can face the anxiety of the individual of being excluded, an anxiety which affects society itself, leading, nowdays, to conflict and violent urban situacions. Towards a return to the city as a common good par excellence and coherent to the Pact of Amsterdam guidelines, the human being can face the crisis of presence through spaces in which executing the ritual of being-in-the-world: creating relationships.

\section{References}

Camara Municipal de Lisboa, Uma cidade para as pessoas, Lisboa

De Martino, E., The Land of Remorse: A Study of Southern Italian

Tarantism, translated by Dorothy L, Zinn. London; Free Association Books. 2005

De Martino, E., Primitive Magic; the Psychic Powers of Shamans and Sorcerers, Bridport: Prism Press, 1988 
D'Angelo, P., (2010), Filosofia del Paesaggio, Quodlibet, pag.23

Heidegger, M, Building Dwelling Thinking, from Poetry, Language, Thought, translated by Albert Hofstadter, Harper Colophon Books, New York, 1971.

Lynch, K., (1964). Title Title Title Title Title Title. Editor. Pages

Krier, R.,(1979), Urban Space, Rizzoli, pag.15

Settis, S., (2017), Architettura e Democrazia, Paesaggio, città, diritti civili, Einaudi Editore 